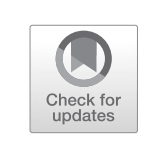

\title{
Microbial Empires: Active Transmission Strategies and Postcolonial Critique
}

While Merriman's With Edged Tools dramatised the deleterious effects of the colonial encounter for European imperialists, four years later, another author would flip the narrative to place Britons in the position of the colonised. This new imperialist project is undertaken by invaders whose intellects are 'vast and cool and unsympathetic', drawing on a discourse that placed Britons in the emotional and intellectual space previously occupied by Africans in the imperial imagination. I am, as some will recognise, referring to H. G. Wells's The War of the Worlds (1898). Wells explicitly invites us to read the story as a critique of imperial relations by remapping the tropical/temperate divide onto the relationship between Earth and Mars. Aligning the Martian invasion with the political history of temperate Europe, he cautions:

Before we judge of them too harshly, we must remember what ruthless and utter destruction our own species has wrought, not only upon animals $[\ldots]$ but upon its inferior races. The Tasmanians, in spite of their human likeness, were entirely swept out of existence in a war of extermination waged by European immigrants in the space of fifty years. Are we such apostles of mercy as to complain if the Martians warred in the same spirit? ${ }^{1}$

${ }^{1}$ H. G. Wells, The War of the Worlds (London: William Heinemann, 1898) pp. 4-5. First serialised in Pearson's Magazine in 1897.

(C) The Author(s) 2022

E. Taylor-Pirie, Empire Under the Microscope, Palgrave Studies in Literature, Science and Medicine, https://doi.org/10.1007/978-3-030-84717-3_6 
As Alan Bewell has argued, Wells encourages critical self-reflection by offering us a 'double text' with 'the voice of the coloniser disquieted by the voice and experience of the colonised'. ${ }^{2}$ Despite the haunting 'ulla ulla' of the Martians, these colonisers have no narrative voice, instead mutely reflecting British imperial attitudes back to the reader. Through the destruction of London and the establishment of the Red Weed, readers are confronted with a topographic transformation akin to the 'ecological cris[e]s' brought about by practices of colonisation, wherein 'entire worlds were lost or transformed' by European sanitation and cultivation projects (xii). As he walks now unfamiliar streets overtaken by the 'tropical exuberance of the Red Weed', Wells's narrator asserts that he found about him 'the landscape-weird and lurid — of another planet' (240). Such a transformation echoes the introduction of European plant species into colonial space but also invokes the latent threat that tropical vegetation might reverse the power dynamic and de-cultivate the metropole. The unstable binary between coloniser and colonised is invoked at the beginning of the novel when the narrator notes that men naïvely imagined the Martians as 'perhaps inferior to themselves and ready to welcome some missionary enterprise' (2). In With Edged Tools, Merriman employs a strikingly similar environmental aesthetic, characterising the Simiacine plateau as 'a strange landscape' with trees that had 'monopolised vegetable life, and slew all comers. It was like some stray tract of another planet, where the condition of living things was different' (200).

Both authors-as Bewell notes of The War of the Worlds—write 'disease [as] a more important factor in the history of empire than military or technological power' (xiii). He points to the 'black smoke' as a form that reaches forward in time to the possibilities of biological warfare (fully realised during the First World War) and backward to the miasmatic atmospheres that were so associated with epidemics in the pre-germ theory imagination. Since at least the seventeenth century, the suffering of Europeans from unfamiliar illness in tropical regions was understood via a combination of miasmatism - the belief that disease issues from the environment via misty vapours, noxious air, and effluvia-and humoralism. The latter-loosely defined-implicated climate in ill-health because the high external temperatures of the tropics were thought to cause imbalance in the natural humours of European bodies. Such imbalances were

\footnotetext{
${ }^{2}$ Alan Bewell, Romanticism and Colonial Disease (Baltimore: Johns Hopkins University Press, 1999) p. xii.
} 
constitutive of disease in and of themselves or were predisposing factors in the contraction of other environmentally borne illnesses. ${ }^{3}$ Another competing theory was contagionism, which posited that disease was transmitted by person-to-person contact via touch or breath, associating illness primarily with people rather than with the environment. This was an association that facilitated the stigmatisation of indigenous colonial populations as themselves pathogenic, and later, with the popularisation of germ theory, as reservoirs of disease. ${ }^{4}$ As Prashant Kidambi notes in relation to plague outbreaks in India, the differences in these doctrines are most notable in regard to preventative action: 'whereas contagionist theory entailed a confinement of the human body in combating disease, [miasmatism] emphasized the need to ameliorate its underlying "environmental causes". 5

By the 1890s, miasmatism had lost considerable currency in the wake of the popularisation of the germ theory of disease, which implicated distinct microorganisms in the production of illness. However, miasma continued to be an ontologically useful concept well into the twentieth century. As Jessica Howell has explored, writers mobilised miasma in a variety of contexts for the 'unique rhetorical opportunities' it embodied. ${ }^{6}$

\footnotetext{
${ }^{3}$ Whilst 'imbalance' was occasionally used in the vague sense that is suggested by my phrasing here, it is not my intention to undersell its intellectual specificity. It was often invoked to refer to increased neurological irritability or loss of tension in the nervous system, a depressing of vital energy, disruption of the biochemical functioning of the internal organs, and suspension of digestive capacity leading to autointoxication. The basic principle of the importance of the continuous biochemical regulation of the internal environment is preserved in the homeostatic response, based on work by French physiologist Claude Bernard in the 1860s and expanded and named by Walter Bradford Cannon in the 1930s. Homeostasis refers to the processes by which the body maintains an optimal state by regulating body temperature, $\mathrm{pH}$, and concentrations of sodium, potassium, glucose, carbon dioxide, and oxygen.

${ }^{4}$ Native populations were considered to be reservoirs for parasites owing to their 'uncleanly habits'. For a fuller discussion of the racial politics of tropical hygiene, see: Daniel Barron, 'Tropical Medicine's Contribution to Colonial Racism' Crossroads 3.1 (2008) 86-91; David N. Livingstone, 'Tropical Climate and Moral Hygiene: The Anatomy of a Victorian Debate' British Society for the History of Science 32.1 (March 1999) 93-110; Warwick Anderson, 'Immunities of Empire: Race, Disease, and the New Tropical Medicine, 1900-1920' Bulletin of the History of Medicine 70.1 (Spring 1996) 94-118.

${ }^{5}$ Prashant Kidambi, "An infection of locality": plague, pythogenesis and the poor in Bombay, c. 1896-1905' Urban History 31.2 (2004) 249-67 (p. 251).

${ }^{6}$ Jessica Howell, Exploring Victorian Travel Literature: Disease, Race, and Climate (Edinburgh: Edinburgh University Press, 2014) p. 15.
} 
This was not only a stylistic strategy but reflected indistinct conceptual borders, as well as fluctuating and sometimes contradictory conceptualisations of tropical illness. Ronald Ross argued, for example, that Patrick Manson's belief in the mid-1890s that parasitic spores in the water or air might spread malaria was proof that he was 'still under the influence of the miasmatic theory'. ${ }^{7}$ Ross later also used miasmatism to contextualise vector transmission. His insistence that 'malaria is due to a miasma given off by the marsh, but the miasma is not a gas or vapour-it is a living insect $[\ldots]$ the anopheles themselves are the malarial miasma', articulates complex intersections between competing theories of infection. ${ }^{8}$ The tenets of humoralism, miasmatism, and contagionism came together to articulate the idea that microorganisms - supported and propagated variously by particular environments and by human-to-human contact-caused disease by infiltrating the body and disrupting its internal balance (soon to be understood in the language of immunology). As Michael Worboys has illustrated, a plurality of germ theories of disease flourished between 1865 and 1900, in which 'disease-germs' could mean many things ranging from bacteria, parasites, and helminths, to poisons, fungi, and chemical ferments. ${ }^{9}$ Thus the distinctions between miasmatism, contagionism, and germ theory are difficult to tease apart; if germs existed in-and were supported by-environments and bodies, then disease was simultaneously 'fixed in the landscape' and 'frighteningly mobile'. ${ }^{10}$

There has been a wealth of scholarship focusing on the impact of germ theory on cultural understandings of health, disease, and identity, and on the cultural currency of ideas about contagion and immunity. Less attention, however, has been given to the impact of vectorism and active transmission strategies, especially in relation to literature. In this chapter, I explore how parasites and their vectors provided the medico-literary imagination with new forms with which to tell stories about empire, arguing that the use of military systems to conceptualise human-microbe interactions perpetuated and tacitly legitimised structural violence in colonial

${ }^{7}$ Ronald Ross, Memories of Sir Patrick Manson (London: [privately printed], 1930) p. 39.

${ }^{8}$ London, LSHTM. RC. GB 0809 Ross/105/06/50. 'The Practice of Malaria Prevention by Ronald Ross, Major I.M.S. Ret. Professor of Tropical Medicine, University of Liverpool', pp. 3-4 [emphasis in original].

${ }^{9}$ Michael Worboys, Spreading Germs: Disease Theories and Medical Practice in Britain, 1865-1900 (Cambridge: Cambridge University Press, 2000) p. 2.

${ }^{10}$ Susan Cannon Harris, 'Pathological Possibilities: Contagion and Empire in Doyle's Sherlock Holmes Stories’ Victorian Literature and Culture 31.2 (2003) 447-66 (p. 458). 
medicine. I close read H. G. Wells's The War of the Worlds (1898) and John Masefield's Multitude and Solitude (1909), alongside parasitologists' characterisations of parasite-vector-host relationships, to excavate how the microbiological imagination made its mark on anxious imperial fictions in which ontological uncertainty and declining confidence in the longevity of British geopolitical dominance were aggregated. I then broaden out this analysis to consider how vectorism and active transmission strategies gave new currency to gothic forms like the vampire. Building on recent scholarship on Bram Stroker's Dracula (1897), I place vampirism in the contexts of the research and professional self-fashioning of parasitologists, as examined throughout this book, to explore how new understandings of disease brought to the fore the discomforting agency of non-human vectors.

\section{The Violence of Medicine and the Fever of War}

In his contribution to $A$ System of Medicine (1897), British physician Surgeon-General Joseph Fayrer illustrated the entanglements between competing theories of disease causation, particularly regarding fever diseases in the tropics. He insisted that 'the effects of heat, cold, moisture, and other telluric and meteorological conditions' might themselves cause fever, or may 'render the body a congenial subject for the development of microorganisms which act as causes, either directly or by the toxic effects they produce', or may 'favour the action of telluric miasmata'. He then expanded the possibilities further by concluding:

[I]t seems probable that they are nearly allied to each other etiologically, and that a combination of the aforesaid causes, acting on individuals of a certain age, race and personal susceptibility, and under the influence of insanitary surroundings, may determine the types assumed. ${ }^{11}$

These observations do little to narrow down the causes of disease and are revealingly housed in a section of the book entitled 'Diseases of Uncertain Bacteriology'.

In his widely read textbook Tropical Diseases (1898), Patrick Manson also kept climate, environment, and germs in play by asserting 'nearly all

${ }^{11}$ Joseph Fayrer, 'On the Climate and Some of the Fevers of India' in A System of Medicine by Various Writers vol II. ed. by Thomas Clifford Allbutt (London: Macmillan and Co., 1897) pp. 295-352 (p. 313). 
diseases, directly or indirectly, are caused by germs' but that these 'demand certain physical conditions for their well-being'. ${ }^{22}$ He upheld a common stigmatisation of the natural abundance of the tropics by implying that the physical conditions of the tropical world are particularly favourable to pathogenic life: 'just as the flora and fauna of the tropical world are infinitely richer in species than those of colder climates, so there is a corresponding distribution in the wealth and poverty of pathogenic organisms' (xvi). The peculiar geographical ranges of many tropical diseases can be explained by their reliance on animal vectors or on particular soils, which, in turn, depend on a more or less tropical climate, he asserted. In this way, the discovery of vector transmission 'shattered the simplicity of the germ theory of disease'. ${ }^{13}$ Now disease could be conceived as an active process, caused by microorganisms, transmitted by insect vectors, and supported by tropical environments. Parasitologists thus redefined the relationship between disease and environment in ways that retained the tropicaltemperate divide. ${ }^{14}$

In redefining the colonies as places of parasites and vectors, parasitologists drew attention to a third realm where disease-causing organisms operated: the interstitial and still mysterious world inside vectors and human bodies. John Masefield employed this concept when trying to conceptualise the trypanosome for a popular audience in his 1909 novel Multitude and Solitude:

Very anxiously, after preparing the slide for observation, [Roger] focussed the lens, and looked down into the new, unsuspected world, bustling below him on the glass. He was looking down on a strange world of discs, among which little wriggling wavy membranes, something like the tails of tadpoles, waved themselves slowly, and lashed out with a sort of whiplash snout [...] He watched them for a minute or two horrified by the bluntness and lowness of the organism, and by its blind power. It was a trembling membrane a thousandth part of an inch long. It had brought Lionel down to that

\footnotetext{
${ }^{12}$ Patrick Manson, Tropical Diseases. A Manual of Diseases of Warm Climates (London: Cassell and Company, 1898) p. xii.

${ }^{13}$ Anne Marie Moulin, 'Tropical without the Tropics: The Turning-Point of Pastorian Medicine in North Africa' in Warm Climates and Western Medicine: Emergence of Tropical Medicine, 1500-1900 ed. by David Arnold (Amsterdam: Rodopi, 1996) pp. 160-80 (p. 160).

${ }^{14}$ Rod Edmond, 'Returning Fears: Tropical Disease and the Metropolis' in Tropical Visions in an Age of Empire ed. by Felix Driver and Luciana Martins (Chicago: University of Chicago Press, 2005) pp. 175-94 (p. 181).
} 
restless body on the bed. [...] It was the visible pestilence, the living seed of death, sown in the blood. (245)

Masefield's 'strange world of discs' finds conceptual common ground with the idea of separate worlds, which Ross uses to piece together the life cycle of parasites found in mosquitoes: 'I believe the [parasites] are meant for men, as well as reinfecting the grubs, of course; hence their being discharged into two worlds.$^{15}$ Here he refers to their presence in stagnant water and in human bodies.

The two worlds rhetoric is also reflected in Wells's collapsing of telescope and microscope at the beginning of The War of the Worlds. In using this formulation, Wells erects a kaleidoscopic relationship between Martians, humans, and microbes that underpins the ensuing narrative:

As men busied themselves about their affairs they were scrutinized and studied perhaps almost as narrowly as a man with a microscope might scrutinize the transient creatures that swarm and multiply in a drop of water. (1)

As I explored in my third chapter, the emergence of a visual culture concerning microorganisms encouraged narratological forms that collapsed the tropical and microscopic 'worlds' into one. By placing empire under the microscope, Wells makes use of a rhetorical strategy reminiscent of Arthur Conan Doyle's 'Life and Death in the Blood' (1883). Indeed, there is more to connect these narratives than we might think; Wells's reimagining of the imperial capital as a body 'inflamed' by Martian invaders mirrors in reverse Conan Doyle's projection of the flora and fauna of British India onto a bloodscape of arteries and veins. Whilst Conan Doyle asks us to imagine shrinking down to microscopic stature to travel through a sick body, Wells makes the body macroscopic-his narrator remarking as he walks 'through the scarlet and crimson trees towards Kew' that 'it was like walking through an avenue of gigantic blood drops' (241). The London landscape stands in for the human body, a symbolic conflation compounded by references to the 'skin' of planet Earth and to the 'inflammation' caused by the Martians (54). ${ }^{16}$ The narrator aligns the Martian

\footnotetext{
${ }^{15}$ Ronald Ross, Memoirs, p. 176 [Emphasis in original].

${ }^{16}$ Wells's characterisation of the Martian cylinder as like a 'poison dart' piercing the 'skin' of the planet again aligns the novel with Conan Doyle, who frequently employs the imagery of puncture by poison arrows to conceptualise the threat of foreign bio-contaminants (see 'Detecting the Diagnosis').
} 
invasion directly with the invasion of pathogenic organisms when he notes that, in the hours following their arrival, 'the fever of war that would presently clog vein and artery, deaden nerve and destroy brain, had still to develop' (54).

Thus, whilst Wells's story of a war between two worlds with starkly different morphologies is usually read as an imaginative rendering of the power dynamic between Britain and her colonial territories-or an anxious challenging of the evolutionary hierarchy-it also serves to analogise the somatic war between humans and microorganisms. At the end of the novel, the Martians are slain, not by armies of men, but by the 'putrefactive and disease bacteria against which their systems were unprepared'bacteria to which humans, through years of coadaptation, have become immune. These once formidable germs are now our 'microscopic allies'. As Wells's narrator explains, 'by the toll of a billion deaths, man has bought his birthright to the earth, and it is his against all comers'. Extending Wells's microscopic frame narrative, the 'toll of a billion deaths' might just as readily describe the successful immune response, with our 'microscopic allies' as white blood cells winning for man his birthright to his own body: 'we have developed resisting-power; to no germs do we succumb without a struggle' (168).

The struggle against invasion by aliens and invasion by pathogens, if not strictly analogous, is certainly a kindred one with a curiously shared vocabulary. Wells's description of the Martians as like 'octopuses' with 'lank tentacular appendages' finds a parallel in Manson's descriptions of ex-flagellated malaria parasites as 'strange, weird, octopus-like creature[s] with long, whipping, curling, lashing, tentacle-like arms' ${ }^{17}$ This kind of comparison was a common technique for conceptualising not just the appearance of microorganisms but also their mode of existence, as when Ross asserted in defence of the malaria parasite: 'if these bodies are not endowed with an independent life, then eels, snakes and worms are dead creatures'. ${ }^{18}$

Just as Roger in Multitude and Solitude is struck by the incongruity between the 'lowness' of the trypanosome's tadpole-like appearance and its 'blind power', Wells's unnamed narrator struggles to reconcile the

${ }^{17}$ Patrick Manson, 'The Goulstonian Lectures on the Life-History of the Malaria Germ Outside the Human Body', The Lancet Vol. I (1896) p. 696.

${ }^{18}$ Ronald Ross, 'Surgn.-Lieut.-Col. Lawrie and the Parasite of Malaria' Indian Medical Gazette 11.10 (1896) 1-13 (p. 6). 
Martians' degenerated morphology with their technological prowess. In 1896, Manson made use of a similar schema to conceptualise the methods by which parasites complete their life cycles within the bodies of vectors and hosts. He described the filaria parasite as having a 'weapon' in the form of a 'very elaborate and powerful oral armature-a piercing apparatus which it seems always eager to use'. ${ }^{19}$ In the lecture delivered before the Royal College of Physicians of London and reprinted in The Lancet and the British Medical Journal, Manson contemplated the evolutionary adaptations of parasites to vector transmission. In the process, he decentres the human by describing the adjustments that 'nature' has made to ensure the success of the parasite:

[I]t is very curious and instructive to watch the behaviour of the phagocytes [immune cells] towards the plasmodium [malaria parasite], and to mark how Nature by means of corpuscular sheathing protects the parasite from harm in this quarter. (317)

He uses comparative pathology to draw attention to the parallels between the sac in which Filaria resides and the red blood cell in which Plasmodium resides. 'Nature', he argues, has 'sheathed' both to prevent Filaria prematurely using its 'weapon' on the blood vessels and to hide Plasmodium from attacks by phagocytes. 'The filaria is sheathed to prevent its committing suicide,' propounds Manson, 'the plasmodium is sheathed to protect it from being murdered' (317).

In using the emotive language of murder and suicide, Manson makes use of a linguistic strategy that Catherine Belling recognises as a common feature in narratives that structure encounters between humans and disease. She argues that in engaging the microbe as an anthropomorphic subject, whether as protagonist or as villain, we relinquish our own centrality and risk the vertiginous view of ourselves as no more than a setting or environment for microbial proliferation'. ${ }^{20}$ This vertiginous view certainly underscores Manson's lecture in which he delineates an uncomfortable rendering of natural selection that does not prioritise humanity. Drawing us in to what he calls the 'little drama' of Filaria, he emotively

\footnotetext{
${ }^{19}$ Patrick Manson, 'The Goulstonian Lectures on the Life-History of the Malaria Germ Outside the Human Body', British Medical Journal, 1.1838 (21 March 1896) 712-17 (p. 712).

${ }^{20}$ Catherine Francis Belling, 'Microbiography and Resistance in the Human Culture Medium’ Literature and Medicine 22.1 (2003) 84-101 (p. 86).
} 
describes the processes by which parasites evade the immune system. A phagocyte may inspect a red blood cell by 'touch[ing] it with its pseudopodia first at one point and then at another $[\ldots]$ suspicious apparently that things were not quite as they should be'. However, the deception always prevails and the 'vigilant watchman [leaves] the masked parasite and move[s] away'. ${ }^{21}$ Manson was likely inspired to use such language by a letter he received from Ross in July the preceding year in which Ross described the interactions between a plasmodium and three phagocytes beneath the microscope. He wrote:

[The parasite] was not killed [by the phagocyte] or sucked in; but kept poking him in the ribs in different parts of the body. I was astonished; \& so apparently was the phagocyte. He kept at this for about $1 / 4$ hour $\&$ then went away across two fields \& went straight at another phagocyte! [...] after 50 minutes the beast seemed to be getting tired, when a very curious thing happened; a third phagocyte came at him with mouth open $[\ldots]$ but had no sooner got near him when the flagellum left his fallen foe \& attacked the new one holding on and shaking like a snake on a dog. In one minute the third phagocyte turned sharp round \& ran off howling!!!-I assure you. I won't swear I heard him howling, but I saw him howling. It went right across the whole field, the flagellum holding onto his tail $[\ldots]$ So was the fight between the flagellum \& the three phagocytes. I shall write a novel on it in the style of the Three Musketeers. ${ }^{22}$

Ross's characterisation of the immune response as like the exploits of the three musketeers is continuous with his use of historical tales of chivalrous adventure to contextualise parasitology research in relation to imperial politics (as explored in chapters one and two). Although the more passionate digressions were omitted from Manson's lecture, he included a brief outline of the episode as an illustration of the parasite's ability to actively attack and defend itself, dubbing it 'The Adventures of a Flagellum'. Such episodes demonstrate the proximity of scientific and literary forms in professional science communications as they jointly translated medicine into war.

${ }^{21}$ Manson, 'The Goulstonian Lectures', p. 713.

${ }^{22}$ Letter to Manson dated 18 July 1895 quoted in Ronald Ross, Memoirs; with an Account of the Great Malaria Problem and Its Solution (London: John Murray, 1923) pp. 165-67 (pp. 166-67). 


\section{Insect Wars ANd Microbial Thugs}

The military politics of colonial warfare were often expressed via a medical register for popular audiences, as when British-born physician and explorer Arthur Torrance impressed on his readers that 'a victory in Siam or East Africa is a victory in America and Europe as well' referring not to colonial conquest, but to the 'warfare against the tiny germs that spread great plagues'. ${ }^{23}$ British colonial administrator Charles Bruce (governor of Mauritius, 1897-1903) revealingly dubbed the London and Liverpool schools of tropical medicine 'the intelligence department of the army of medicine in the tropics' ${ }^{24}$ This collision of medical and military language also dominates the publications of parasitologists, facilitating the elision of these two forms of colonial power and control. In Ross's Memoirs, he uses the language of warfare to conceptualise the life cycles of parasites, writing of battles and bullets, describing mosquito eggs as 'cartridge shaped', and envisioning stained parasitic bodies inside cells as 'bullets in a bag' (274). When describing the diurnal activity of the parasite responsible for elephantiasis, Filaria sanguinis hominis, Manson had drawn on a similar lexis, insisting that no embryos are to be found in the blood circulation during the day but that at 'about six or seven o'clock in the evening, with "military-like punctuality", as Cobbold expresses it, they march to their night quarters and proliferate'. ${ }^{25}$

These kinds of military similes - the conceptualisation of microbes as bullets and their vectors as guns-dominates the historiography of tropical medicine, which Warwick Anderson summarises as 'the glorious history of "insect wars" [and] tales of the triumph of germ theory in the tropics'. ${ }^{26}$ By interpolating military forms into medicine and viewing their work as an extension of military warfare, parasitologists characterised tropical medicine as part of the machinery of national defence. When developing measures for mosquito control, Ross suggested setting up 'mosquito brigades',

${ }^{23}$ Arthur Torrance, Tracking Down the Enemies of Man (1928; London: Alfred A. Knopf, 1929) p. 318.

24 'The Imperial Aspects of Tropical Medicine' British Medical Journal2.2285 (15 October 1904) 1022-23 (p. 1023).

${ }^{25}$ Patrick Manson, The Filaria Sanguinis Hominis and Certain New Forms of Parasitic Disease in India, China, and Warm Countries (London: H. K. Lewis, 1883) p. 8.

${ }^{26}$ Warwick Anderson, 'The Third World Body' in Companion to Medicine in the Twentieth Century ed. by Roger Cooter and John Pickstone (London: Routledge, 2003) pp. 235-45 (p. 236). 
employing terms like 'campaign' and 'operation' to describe local sanitation measures. ${ }^{27}$ In the preface to Mosquito Brigades, and How to Organise Them (1902), he defines the object of the book as showing 'how we can best wage war against mosquitoes'. He ends the preface with a rallying recruitment appeal, mobilising the crusading motif examined in previous chapters:

The reader will perceive that, in fact, I am preaching a general crusade of a more novel and perhaps more useful character than most crusades. I trust that he will volunteer under the flag. (vi)

Just after the outbreak of war in 1914, Ross again invoked the military as an institution that structurally and conceptually corresponded with medicine:

The armies of science, like those of nations, commence in small beginnings and advance in parallel columns. If one column is checked by insuperable difficulties, the others endeavour to outflank the point of resistance; and a victory is often won by this means in science as in war. ${ }^{28}$

Indeed, the Liverpool School of Tropical Medicine had declared a war of its own in 1901:

Few people in this old country appear quite to understand the significance of the new kind of war which is now being started in many parts of the tropical world - notably by the Liverpool School of Tropical Medicine in West Africa $[\ldots]$ the tyranny of the mosquito over the principal civilised towns in the tropics must cease; and cease it will..$^{29}$

Such rhetoric obscured the complexities of the localised control and treatment of parasitic disease, instead suggesting that what was needed was a show of military strength. The mosquito must be unseated, just as so many African rulers had been.

\footnotetext{
${ }^{27}$ Ronald Ross, Mosquito Brigades and How to Organise Them (London: George Philip \& Son, 1902) p. vi.

${ }^{28}$ Ronald Ross, 'The Huxley Lecture on Recent Advances in Science and their Bearing on Medicine and Surgery' The Lancet 184.4758 (7 November 1914) 1079-84 (p. 1079).

${ }^{29}$ London, LSHTM. RC. GB 0809 Ross/70/03. Newspaper cutting 'The War Against Mosquitoes in Sierra Leone' (1901).
} 
The use of martial language in medicine is not unique to the nineteenth century, to tropical medicine, nor indeed to Anglophone medicine. Traditional Chinese medicine (TCM) also uses the language of violence and warfare. The Chinese physician Xu Dachun (Hsü Ta-ch'un) wrote of the parallels between medicine and military conflict in the eighteenth century, asserting that the most effective strategies for treating illness might be found in a military text from the sixth century BCE, Sunzi Binfa (The Art of War by Sun Zi). However, the martial metaphor in TCM operates in a very different context to its Western counterpart given that Chinese military strategies like those elaborated in Sunzi Binfa consider the supreme principle of war is to win without fighting.

Thus, the doctor-patient relationship for TCM is more like that between a general and a king with the doctor-general helping the patient-king to strategise for a peaceful monarchy and avoid armed conflict. In contrast, the martial metaphor as it is invoked in late-nineteenth-century tropical medicine is most often one that dramatises a war between the patientsoldier and the disease-enemy, or else obscures the patient entirely by constructing a direct military stand-off between the doctor-general and an abstracted enemy pathogen-or even death itself. This is the case in novelistic encounters with disease too. In Joseph Hocking's 1915 novel The Dust of Life, British youth Cedric contracts sleeping sickness and 'fight[s] with the disease [...] battl[ing] with the numbing influence'. When he is given medicine, it is described as 'life fighting death' (116). Similar rhetoric can be found in Richard Burton and Verney Lovett Cameron's To the Gold Coast for Gold (1883) where Burton relates his recovery from malaria as a battle between 'Dr Warburg's fever tonic' and the 'Fever-fiend', in which the 'admirable drug $\mathrm{w}[\mathrm{i}] \mathrm{n}[\mathrm{s}]$ the victory' ${ }^{30}$

In Masefield's Multitude and Solitude, the enjoinment of medicine and warfare is even more pronounced; Roger considers the trypanosome to 'battle with the white corpuscles' (156); his friend Lionel's study is stocked solely with copies of The Lancet, British Medical Journal and books on military history; and in one particularly memorable hallucination, Roger is accosted by giant tsetse flies carrying guns:

He began to see an endless army of artillery going over a pass. The men were all dark; the guns were all painted black; the horses were black $[\ldots]$

\footnotetext{
${ }^{30}$ Richard Burton and Verney Lovett Cameron, To the Gold Coast for Gold. A Personal Narrative (London: Chatto and Windus, 1883) p. 239.
} 
Instantly they changed to tsetses, riding on dying cattle. They were giant tsetses with eyes like cannon balls. ${ }^{31}$

The tsetse flies are here made synonymous with 'men with guns', perpetuating the imagery of parasites as deadly ammunition. Mary Kingsley in her Travels in West Africa (1897) also used the metaphor of battle to describe the trials and tribulations of colonial life for British men working in West Africa. These are men whose battles

have been fought out on lonely beaches far away from home $[\ldots]$ sometimes with savages, but more often with a more deadly foe, with none of the anodyne to death and danger given by the companionship of hundreds of fellow soldiers in a fight with a foe you can see, but with a foe you can see only incarnate in the dreams of your delirium. ${ }^{32}$

Here Kingsley expresses the individualism of battle with disease, a battle that patients must take on alone. By identifying the microbial 'foe' as one that 'you can only see incarnate in the dreams of your delirium', she highlights the difficulty in conceptualising not only the relative invisibility of microbes, but also the experience of illness. Masefield paints a strikingly violent image of this experience when Roger hallucinates 'a giant tsetse [...] forcing his mouth open with a hairy bill, so that the trypanosomes might wriggle down his throat'. He imagines that 'a flattened trypanosome, tasting as flabby as jelly, [is] worming over his lips’ (196).

This hideous force-feeding characterises vector transmission as a necessarily violent act that finds congruence with popular characterisations of parasites and their vectors as military assassins, villains, and murderers. In Ronald Campbell Macfie's The Romance of Medicine (1907), he describes the tuberculosis bacillus as 'the most deadly weapon of death', responsible for 'massacres'. He goes on to insist that 'the mouth of the consumptive may scatter more deaths than the muzzles of many guns', depicting the microbe as a 'beau sabreur [...] more ruthless than a Thug, more ravenous than any beast of prey' (143). By invoking Indian Thugs - a religious cult of highway bandits famous for strangling and robbing their victimsMacfie manipulates a discourse of violence and criminality historically associated with Indians to conceptualise pathology in the early twentieth

${ }^{31}$ Masefield, Multitude and Solitude, pp. 195-96.

${ }^{32}$ Mary Kingsley, Travels in West Africa: Congo Français, Corisco and Cameroons (London: Macmillan, 1897) p. 691. 
century. This is an example of a broader phenomenon whereby 'savage' natives and 'savage' microbes were constructed in tandem. Manson, for instance, erected parallels between primitivism and pathology by asserting that 'to the scientific mind the infinitely minute bacterium is just as important as the gigantic elephant [...] a naked savage as a European potentate'. ${ }^{33}$ The European is to the savage, he implies, as the elephant is to the microbe.

Macfie's choice of the Thug reference is given further rhetorical significance in the context of recent scholarship, which has questioned the authenticity of Indian thuggee as represented by the British colonial archive. Postcolonial scholars argue that stories of Indian Thugs were embellished or even invented by an imperial imagination that sought to 'make an ontological and epistemological distinction between the Occident (Europe, the West) and the Orient (the East)'. ${ }^{34}$ As Subramanian Shankar has argued, the concept of thuggee was weaponised to justify the displacement of native Indian rulers and mark out Indians as targets for disciplinary action under the elaboration of a law-and-order state. ${ }^{35}$ By aligning the causes of disease with indigenous primitivism (in the case of Manson) and a culturally specific criminal practice (in the case of Macfie), writers made similar ontological and epistemological distinctions, paving the way for kindred biopolitical interventions.

In deploying the vocabulary of warfare and military conflict parasitologists like Ross and Manson projected the essentialised violence of military enemies onto depictions of tropical parasites - and by extension the tropical environment. Justin D. Livingstone has identified similar disciplinary rhetorical strategies in what he terms 'fictions of exploration'-fictional narratives written by Victorian naturalists and explorers. This genre was a 'distinctive product of its historical moment' but had considerable aesthetic and formal overlap with travelogues, medical biography, imperial romance, and handbooks of tropical medicine, as I examined in my second chapter. Straddling the line between 'adventurous romance and

${ }^{33}$ Patrick Manson, 'Some Problems in Tropical Epidemiology' Transactions of the Epidemiological Society of London (London: Printed at Bedford Press, 1901) p. 3.

${ }^{34}$ Alexander Lyon Macfie, 'Thuggee: an orientalist construction?' Rethinking History 12.3 (2008) 383-97 (p. 384).

${ }^{35}$ See: S. Shankar, 'Thugs and Bandits: Life and Law in Epicolonial India' Biography 36.1 (2013) 97-123; S. Shankar, Textual Traffic: Colonialism, Modernity, and the Economy of the Text (Albany: SUNY Press, 2001). See also: Sagnik Bhattacharya, 'Monsters in the Dark: The Discovery of Thuggee and Demographic Knowledge in Colonial India' Palgrave Communications 6.78 (2020) 1-9. 
authoritative travel narrative', it was a genre that helped to produce 'cartographies of violence' in which Africa was reimagined as a space of tribal conflict. ${ }^{36}$ Rather than reflecting the complex militarisation and political instabilities of East and Central Africa in the 1870s and 1880s, Henry Morton Stanley, Samuel Baker, and Verney Lovett Cameron used the novelistic mode to 'naturalize a vision of east Africa in which conflict and insecurity are its intrinsic features $[\ldots]$ provid[ing] a case for the stabilising influence of European governance' (81).

As Jing-Bao Nie et al. point out, the martial metaphor (which is still ubiquitous in medicine today) facilitates the 'unintended legitimization and glorification of war and violence', whilst encouraging the uncritical acceptance of sometimes unnecessary intervention and structural violence in medicine. ${ }^{37}$ As a narrative strategy, it encodes and supports particular political and social relationships. Such entangled relationships are exemplified by this Punch cartoon (Fig. 1) which features British Home Secretary Reginald McKenna appealing to the Greco-Roman god of medicine Aesculapius for help with the microbe 'militancy' (probably referring to the political militarism of the Suffragette movement).

The cartoonist suggests that political dissent threatens the health of the nation, a body politic metaphor that highlights medicine as a branch of governmental administration. At the turn of the century, martial metaphors endorsed the structural violence of imperialism through tropical medical discourses that projected racialised understandings of African violence onto 'African' diseases, and thus legitimised the wider military responses of imperial Britain in the name of medicine.

In a lecture given by Ross to the Liverpool Chamber of Commerce in 1899, he compared the practices of politics and science:

In politics, the great powers, somewhat tired of self-development, are endeavouring to extend their possessions and civilisation all over the world. In science, somewhat satiated with our conquests over inanimate matter, we

\footnotetext{
${ }^{36}$ Justin D. Livingstone, 'Travels in Fiction: Baker, Stanley, Cameron and the Adventure of African Exploration' Journal of Victorian Culture 23.1 (2018) 64-85 (p. 71).

${ }^{37}$ Jing-Bao Nie, Stuart Rennie, Adam L. Gilbertson, and Joseph D. Tucker, 'No More Militaristic and Violent Language in Medicine: Response to Open Peer Commentaries on "Healing Without Waging War: Beyond Military Metaphors in Medicine and HIV Cure Research"' American Journal of Bioethics 16.12 (2016) 9-11.
} 


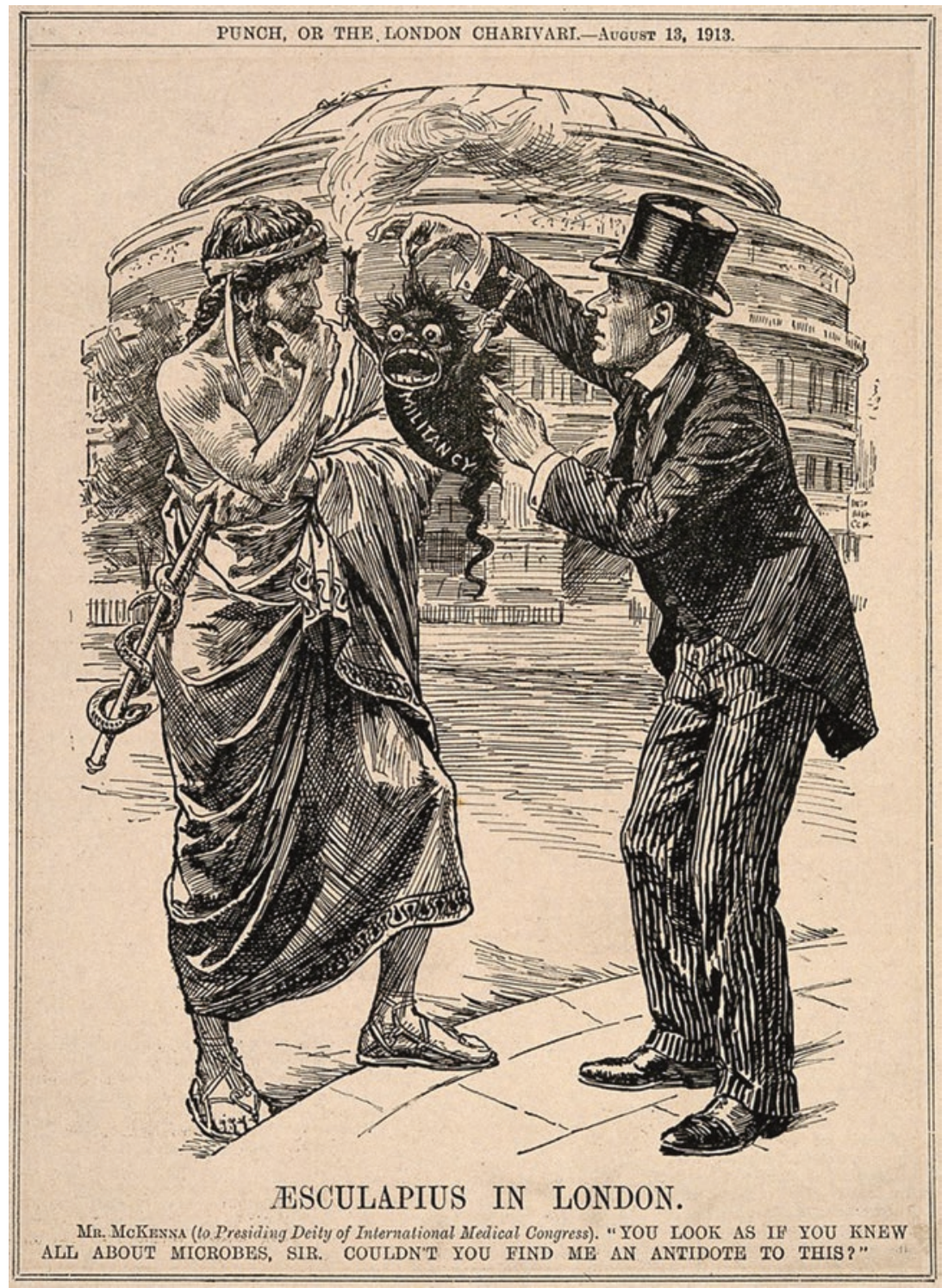

Fig. 1 Punch Cartoon featuring Reginald McKenna as British Home Secretary asking Æsculapius for help with the microbe 'Militancy'. (Reproduced with permission from the Wellcome Collection) 
have recently created what is perhaps the most fundamentally important of knowledges - the experimental science of disease. ${ }^{38}$

'In the very last years of the century', he asserted, 'a new link has been forged between them $[\ldots]$ the conquest of the world will depend on our conquest of invisible atoms'. Whilst the Anglo-Boer war rages in South Africa, 'a much more terrible war has been raging in West Africa for a century', he insists, producing 'a percentage of "casualties" exceeding the battle of Waterloo'. This war is fought between Englishmen and 'king Malaria', without which Britain's armies would have pushed forward 'into the heart of the country without fear of an enemy much more dangerous than any savage tribe to be found in it'. By comparing imperial expansion to dominion over microbes, Ross elides the space between indigenous African communities and pathogenic microbes under the conceptual banner of 'global Others'. If disease is inimical to civilisation-'the backwardnesss of tropical countries as regards civilisation is greatly, or chiefly, due to [malaria]'-the corollary is: so is the existence of indigenous communities.

It is not difficult to see how such rhetoric, espoused as it was during the ascendency of eugenics, would lead to devastating genocides, as well as lasting institutionalised and socialised racism. The semantic violence of the war on disease made it easier to justify public health campaigns in Uganda in the early twentieth century that imposed compulsory examination, isolation, and 'atoxylisation' of those suspected of harbouring the parasite, as well as the forcible depopulation of African landscapes. ${ }^{39}$ When Macfie

${ }^{38}$ London, LSHTM. RC. GB 0809 Ross/67/08. 'The Recent Medical Expedition to West Africa' [lecture delivered to the Liverpool Chamber of Commerce on 27 November 1899].

${ }^{39}$ These and similar campaigns were enacted by major European colonial powers in the context of a transnational response to sleeping sickness epidemics. The establishment of isolation camps in the Belgian Congo was a result of advice given by British parasitologists under the auspices of the Liverpool School of Tropical Medicine. The British adopted similar models including the segregation of the sick, forcibly relocating Africans from their homes in so-called fly belts and forbidding them from hunting and fishing in these regions. See: Daniel R. Headrick, 'Sleeping Sickness Epidemics and Colonial Responses in East and Central Africa, 1900-1940' PLOS Neglected Tropical Diseases 8.4 (2014) 1-8; Maryinez Lyons, 'Public Health in Colonial Africa: The Belgian Congo' in The History of Public Health and the Modern State ed. by Dorothy Porter (Amsterdam: Rodopi, 1994) pp. 365-66; Sara Lowes and Eduardo Montero, 'The Legacy of Colonial Medicine in Central Africa' Cato Institute 8.209 (8 April 2020) https://www.jstor.org/stable/resrep26223. 
dubbed the trypanosome a microbe 'so murderous that it slew in Uganda alone, between 1901 and 1905, no less than 100,000 natives', he consciously shifted the narrative away from the biopolitical violence of imperial administration to focus on the biopolitical violence of disease.

The fever of war, masked intracellular invaders, and murderous microbes-all these linguistic configurations were responding to the same problem, namely representing what remained for most inaccessibly conceptual: the domain of the microbiological. With the emergence of a more formal immunology, especially following Elias Metchnikoff's identification of phagocytes in the 1880 s, writers sought a vocabulary that could encapsulate the inimical relationship between humans and microorganisms. One lexis that came to dominate was that of violence, a form that structured both professional and popular encounters with the microbial world, and, as Lorenzo Servitje has recently explored at length, elided the political space between medical and imperial threat. ${ }^{40}$

At the end of the century, in the wake of the discovery of the role of insect vectors in the transmission of disease, non-human animals were transformed into what Christos Lynteris terms 'epidemic villains'-transmitters and reservoirs of illness. ${ }^{41}$ Non-human vectors took on a 'protagonistic role' in a 'series of epidemic and public health dramas', where epidemiology garnered new narrative power (5). When reviewing Multitude and Solitude, The Graphic explained that the novel's 'accurate' scientific detail was what rendered it a 'gift to fiction in search of a fresher subject than love, murder, or money'. In his 'descriptive ability', Masefield had made the tsetse fly, 'a more vigorously interesting villain than nine others out of ten'. ${ }^{42}$ In this next section, I explore how insect vectors became loci for a plethora of new sanitary concerns related to microbial reproduction and disease transmission. Tensions between the multiplicity of microbic disease and disease as it is individualised in the body of a vector meant that parasites and vectors were often collapsed into one symbolic figure that absorbed and enacted cultural concerns about individual and national breach.

\footnotetext{
${ }^{40}$ Lorenzo Servitje, Medicine Is War: The Martial Metaphor in Victorian Literature and Culture (Albany: SUNY Press, 2021).

${ }^{41}$ See: Christos Lynteris, 'Introduction: Infectious Animals and Epidemic Blame' in Framing Animals as Epidemic Villains. Histories of Non-Human Disease Vectors ed. by Christos Lynteris (London: Palgrave Macmillan, 2019) pp. 1-25.

42 'Trypanosomiasis’ The Graphic, Saturday 18 September 1909, p. 24.
} 


\section{VAMPIRES AND VECTORS}

She had suffered rather severely from the mosquitoes before Christmasand had been almost frightened at finding a wound upon her arm, which she could only attribute to the venomous sting of one of these torturers $[\ldots]$ "He has caught you on the top of a vein. What a vampire! [...] You must always show me any bite of this nature. It might be dangerous if neglected. These creatures feed on poison and disseminate it." ${ }^{43}$

In Mary Elizabeth Braddon's 1896 short story 'Good Lady Ducayne', a young girl called Bella travels to Italy as a companion to an aristocratic woman of uncommonly old age and is there subject to a mysterious illness. Her increasing weakness is attributed to the bites of mosquitoes, which Dr Parravicini insists are preying on her at night. In the passage I quoted above, he characterises the mosquito as a 'vampire' owing to its extraction of her blood and further suggests that the insect might disseminate poison from one place to another. The story later reveals that it is Dr Parravicini himself who is the culprit, dosing Bella with chloroform before extracting her blood for his scientific experiments to prolong Lady Ducayne's life. In an attempt to prevent this dénouement, the doctor attributes her illness to what just one year later Ross would confirm as the transmission route for one of the most high-profile diseases of the British Empire: malaria. Indeed, malaria and mosquitoes were of particular significance to Italy where they both abounded, prompting one lady to write to Ross asking him to 'exterminate the mosquito in Venice! That paradise that is to me an inferno' ${ }^{44}$ Dr Parravincini's misdirection draws our attention to an implied association between vampires, vectors, disease, and blood transfusion that loomed large in the fin de siècle medico-literary imagination. This figuration is also apparent in a perhaps more familiar vampire story published by a lifelong friend of Braddon the following year: Bram Stoker's Dracula.

Scholars have mapped a dizzying array of social, political, and medical concerns onto Dracula, from contagious disease legislation to the ascendency of the New Woman and its associated feminisms; from critiques of capitalism to anxieties about and celebration of queer sexualities; from cholera maps and public health campaigns to fracturing domestic class politics, anti-Semitism, xenophobia, and imperial guilt. As I have explored

${ }^{43}$ Mary Elizabeth Braddon, Good Lady Ducayne (1896; Whitefish: Kessinger, 2004) p. 15.

${ }^{44}$ London, LSHTM. RC. GB 0809 Ross/119/25. Correspondence: Lillian Glenny to Ross, 16 August 1913. 
elsewhere, emerging paradigms in tropical medicine in the 1890s provided a framework that endowed the vampire with especial potency as a metaphor for the double threat of parasite and vector. ${ }^{45}$ Indeed, it is the multivalence of Stoker's polymorphous antagonist that makes him so critically rich:

He can within limitations appear, at will, when and where and in any of the forms that are to him; he can, within his range, direct the elements: the storm, the fog, the thunder; he can command all the meaner things: the rat, the owl, and the bat - the moth, and the fox, and the wolf; he can grow and become small; and he can at times vanish and become unknown $[\ldots]$ he can transform himself into a wolf $[\ldots]$ he can be as bat $[\ldots]$ He can come in mist which he create $[\ldots]$ he come on moonlight rays as elemental dust. (27l)

Able to control the weather, utilise and transform into non-human animals, and change his form in size, shape, and substance, it is easy to see the narratological power of Dracula in the context of competing and indiscrete disease aetiologies. Martin Willis has read this multivalence as an attempt to reconcile modern germ theory with older ideas about disease transmission, whilst Ross G. Forman has argued that the 'temporal cycles, morphological changes, infection and propagation suggested by protozoan disease provide a template' for Stoker's modernist experiments in form. ${ }^{46}$ The Count is at once miasma and microbe, disease and vector, and thus might be read as a biomedical metaphor that sometimes edges-as Rohan Deb Roy has noted of malaria itself-into 'diagnostic jargon' ${ }^{47}$

The conceptual and aesthetic connections between vampirism and malaria are intuitive. Both are 'blood diseases' that cause cyclic fevers and leave their patient-victims feverish and anaemic. They share a biting vector-the vampire's fangs and the mosquito's proboscis even leave similar

${ }^{45}$ See: Emilie Taylor-Brown, "“She has a parasite soul!": The Pathologization of Gothic Monster as Parasitic Hybrid in Bram Stoker's Dracula, Richard Marsh's The Beetle, and Arthur Conan Doyle's “The Parasite"' in Monsters and Monstrosity from the Fin de Siècle to the Millennium ed. by Sharla Hutchinson and Rebecca A. Brown (Jefferson: McFarland and Company, 2015) pp. 12-28.

${ }^{46}$ Martin Willis, “"The Invisible Giant”, Dracula, and Disease' Studies in the Novel 39.3 (Fall 2007) 301-25; Ross G. Forman, 'A Parasite for Sore Eyes: Rereading Infection Metaphors in Bram Stoker's Dracula' Victorian Literature and Culture 44 (2016) 925-47 (p. 927).

${ }^{47}$ See: Rohan Deb Roy, 'Mal-Areas of Health: Dispersed Histories of a Diagnostic Category’ Economic and Political Weekly 42.2 (13 January 2007) 122-29 (p. 122). 
puncture wounds. Both are repelled by garlic (a natural antibiotic and mosquito repellent) and both are most active at night. Even before the discovery of its mosquito vector, malaria, like vampirism, had long been associated with the night; Dr John Mitchell, for example, wrote in 1849 'whatever may be [the] cause [of malarial fevers], it seems to have activity almost solely at night. Darkness appears to be essential to either its existence or its power' ${ }^{48}$ These basic aetiological overlaps are perhaps a result of the vampire's historical role as a folkloric explanation for disease in preindustrial societies. As Paul Barber argues, such supernatural theories, although incorrect, are 'usually coherent, cover all the data, and provide a rationale for some common practices that seem, at first glance, to be inexplicable'. ${ }^{49}$ Barber argues, for example, that

the pneumonic form of the plague causes the victim to expel blood from the mouth, and the combination of visible blood with unexpected and quite sudden deaths may have contributed to the belief that vampirism was responsible for this disease. (42)

Vampires can certainly be mapped onto more than one illness; they have been read variously as metaphors for syphilis, HIV, cholera, plague, leprosy, tuberculosis, and rabies, among others. Contemporaneous reviewers of Stoker's novel highlighted the vampire's analogy to contagious disease, asserting 'Count Dracula is a vampire of the most malignant kind $[. .$.$] he$ carries contagion with him' and 'vampirism is propagated, like cholera, by contagion'. ${ }^{50}$ As Willis has pointed out, Stoker's vampiric aetiologymuch like cholera-was enmeshed within competing discourses of contagionism, miasmatism, and sanitary science in the 1890s.

Stoker was certainly no stranger to medical concerns; as a child, he suffered from an undiagnosed illness that left him bedridden. For entertainment, he listened to 'horror stories' told by his mother, Charlotte, which — as others have suggested - may have instigated his interest in the folk power of disease, informed as they were by her experiences of the cholera outbreak in Sligo, Ireland, in the 1830s. Her characterisation of cholera as a sulphurous cloud hanging over the town likely influenced

${ }^{48}$ J. K. Mitchell, On the Cryptogamous Nature of Malarious and Epidemic Fevers (Philadelphia: Lea and Blanchard, 1849) p. 51.

${ }^{49}$ Paul Barber, Vampires, Burial, and Death: Folklore and Reality (New Haven: Yale University Press, 1990) p. 5.

50 'Notes on New Books' Illustrated London News, Saturday 17 July 1897, p. 23. 
Stoker's earlier short story 'The Invisible Giant' (1882), which sees a vaporous giant besiege a city with illness. Reading this story in conversation with Dracula, Willis argues that it was a text that allowed Stoker to experiment with the imaginative power of disease as a monstrous gothic figure before developing it more fully in Dracula. ${ }^{51}$ In the latter novel, Stoker's continued investment in the aesthetics of miasmatism can be read through references to 'little specks of dust' and 'white mist', both of which herald the presence of vampires. Dracula's tomb at Carfax even gives off a 'malodorous air [...and] an earthy smell, as of some dry miasma, which came through the fouler air [...] composed of all the ills of mortality', directly connecting vampirism to the vocabulary of environmental theories of disease transmission (284).

Dracula's reliance on miasmatic environments and his importation of boxes of earth from his homeland evoke the quintessential disease of 'bad air'-mal'aria, which had long been associated with marshy effluvia. And yet, whilst Dracula's propagation is associated with miasmatic environments, he does not transmit his vampirism through this means, or indeed through contagion. Rather his desire to 'create an ever-widening circle of semi-demons to batten on the helpless in London' is (or would have been) effected, like parasitic disease, through a series of 'blood meals' (his drinking of Lucy and Mina's blood and his forcing of them to drink his). Thus, Stoker's novel might be read in the context of developments in vector biology and tropical medicine, which had highlighted the significance of blood in the diagnosis of infection and the role of non-human bloodsucking intermediates, like mosquitoes, in the propagation of disease.

In 1883, British-born American doctor Albert King had suggested that diseases like malaria might be transmitted by blood-sucking insects, comparing the phenomenon to the practice of inoculation:

viewed in light of our modern "germ theory" of disease, the punctures of proboscidian insects, like those of Pasteur's needles, deserve consideration as a probable means by which bacteria and other germs may be inoculated into human bodies, so far as to infect the blood and give rise to specific fevers. ${ }^{52}$

${ }^{51}$ Martin Willis, “"The Invisible Giant”, Dracula, and Disease' Studies in the Novel 39.3 (Fall 2007) 301-25.

${ }^{52}$ A. F. A King, 'Insects and Disease-Mosquitoes and Malaria' Popular Science Monthly 23 (September 1883) 644-58 (p. 644). 
King's comparison between proboscis and needle casts a different light on the blood transfusions in the novel, which Jessica Howell argues exist at a 'historical pivot point between the symbolic and biochemical resonances of blood, between anxieties about and hopes regarding the possibilities afforded by the transfer of blood and blood substances' ${ }^{53}$ These hopes and anxieties might be read in Lucy's transfusion of blood from Arthur Holmwood, who we are informed has 'blood so pure that [they] need not defibrinate it' (143). Although critics often read this as an endorsement of Holmwood's superior class pedigree, it could equally refer to the absence of erythrocytic pathogens, a medical preoccupation ascertained earlier in the novel when Dr Seward examines a sample of Lucy's blood microscopically: 'I was actually able to test the quality of her blood [...] I secured a few drops of the blood and analysed them' (130). ${ }^{54}$

Readings of the Count as allied metaphorically with malaria and metonymically with the mosquito are strengthened by the novel's position within a constellation of texts that explicitly make these connections. As I mentioned at the beginning of this section, this was the case with Braddon's Good Lady Ducayne published the preceding year. Moreover, Dracula has an acknowledged debt to Sheridan Le Fanu's earlier vampire tale Carmilla (1872), which also drew on the lexis of disease- 'fever', 'plague', 'a strange epidemic'-and explicitly on malaria to conceptualise the vampire. ${ }^{55}$ In response to hearing a funereal hymn, Carmilla is herself described as 'trembl[ing] all over with a continued shudder as irrepressible as ague'. ${ }^{56}$ Her nightly visitations are conceptualised as 'only a fever passing by, or some other malady, as they often do [... $\operatorname{knock}[i n g]$ at the door, and not being able to get in' (155). When Laura is sold a charm to ward off 'oumpires', Carmilla explains that it works because it has been 'fumigated, or immersed in some drug, and is an antidote against the malaria' (156).

\footnotetext{
${ }^{53}$ Jessica Howell, Malaria and Victorian Fictions of Empire (Cambridge: Cambridge University Press) p. 175.

${ }^{54}$ Forman conversely suggests that the lack of a more explicit microscopic analysis of blood in the novel is a sign of Van Helsing's 'unorthodox' medical practices and reflective of his belief that Lucy's ailment is not physical but supernatural.

${ }^{55}$ Joseph Bierman recognises this debt in the original placement of Castle Dracula in Styria. This was later rewritten. See: Joseph Bierman, 'The Genesis and Dating of Dracula from Bram Stoker's Working Notes' Notes and Queries 24 (1977) 39-41.

${ }^{56}$ J. Sheridan Le Fanu, 'Carmilla' in In a Glass Darkly, vol III (London: R. Bentley and Son, 1872) pp. 49-270 (p. 116).
} 
Whilst malaria provided the literary imagination with an aesthetic with which to conceptualise vampirism, the vampire became a cultural referent for communicating the challenges of tropical travel and contextualising imperial sanitation projects. In 1896, for example, an article about mosquitoes in the Sheffield Weekly Telegraph characterised tropical travel as dominated by the threat of 'gnat bites and other insect vampires' ${ }^{57} \mathrm{~A}$ writer complaining that trade illustrations of mosquito nets encouraged naïve travellers to hang their nets incorrectly, similarly warned against being exposed to the bites of the 'little vampire[s]' that cause malaria. ${ }^{58} \mathrm{~A}$ writer reporting on the work of the Liverpool School of Tropical Medicine in West Africa for the Liverpool Daily Post also discussed the transmission of disease in relation to 'insect vampires'. ${ }^{59}$

In a speech given to students at Aberdeen University, British surgeon Frederick Treves drew on the popular detective/doctor dyad explored in my third chapter to erect a direct analogy between the vampire and the malarial mosquito. As reported by the Pall Mall Gazette in 1906, he said:

[T] here were few detective stories that could surpass the true tale of the tracking of the miscreant malaria [...] for all time this bringer of disease has been an evil genius, a vampire of the marsh, feeding upon its victim in the dead of the night. Now the ghost was laid, and the mystery was reduced to a few cells which could be kept in a bottle, and grown as tamely as a gardener rears cabbages. ${ }^{60}$

The gothic mode allows Treves to emphasise malaria as a protagonist in a disciplinary drama (miscreant, evil genius), as a supernatural threat to be eliminated by modern medicine (vampire, ghost), and as a microbe to be 'kept in a bottle' and 'grown tamely'. It is a vision of culturing nature that dovetails with what Paul S. Sutter has identified as a discourse of environmental 'mastery' in tropical medicine. Employing the concept of 'unruliness', Sutter argues that imperial sanitary projects were dominated by a form of 'tropical triumphalism' that emphasised environmental management as a central activity of imperial power. Such language, he argues, exposes the extent to which the nature/culture divide has historically 'been a product of, and crucial strategy for, imperial and high-modernist

\footnotetext{
57 'The Mosquito Plague' Sheffield Weekly Telegraph, Saturday 11 July 1896, p. 8.

${ }^{58}$ Alan Field, 'Mosquito Nets' Field, 13 May 1905, p. 779.

59 'News of the Day' Liverpool Daily Post, Tuesday 20 March 1900, p. 4.

60 'Sir Frederick Treves at Aberdeen' Pall Mall Gazette, Thursday 22 February 1906, p. 7.
} 
management'. He reads the triumphalist sentiment surrounding the completion of the Panama Canal as a 'formative expression of the dominant modernist approach to nature' ${ }^{61}$ By combining this triumphalism with the gothic figure of the vampire, writers like Treves were able to strengthen the ideological power of Western medicine as a form of knowledge that banished superstition and reduced 'monstrous threats' to 'a few cells'.

In 1925, then director of the London School of Tropical Medicine, and president of the Royal Society of Tropical Medicine and Hygiene, Andrew Balfour used this formulation to conceptualise the problems posed by tropical illness. In his presidential address given at the Royal Institute of Public Health in Brighton, he used the introduction to Patrick Manson's famous textbook as a prompt to ask which diseases commonly found in the colonies might be truly termed 'tropical'. African sleeping sickness sprung immediately to mind for Balfour, since it was one of only a few diseases truly limited in geographical range. Despite this, its influence extends well beyond the 'Dark continent' he asserts, by affecting imperial trade and commerce. Both it and Chagas' disease- the 'human trypanosomiasis of South America'-are limited by the distribution of 'certain insects $[\ldots]$ which love the darkness rather than the light and, like vampires, feed upon the blood of man'. ${ }^{62}$

Balfour revisited the spirit of this analogy again in a speech given at the Guild Hall in Eccleston Square later that same year. In 'Malaria as an Enemy of the British Empire', he characterised malaria as a disease which 'exercises its powers for evil' by draining the life force out of individual and nation, gripping the empire with 'a strangle-hold'. 'The mouse we know aided the lion', he insisted,

but something infinitely smaller than any mouse worries and perplexes the British lion year in and year out [...] How many young and active men, potential empire builders, seek the tropics for a career and instead, owing to acute malaria, find there a grave! ${ }^{63}$

${ }^{61}$ Paul S. Sutter, 'Triumphalism and Unruliness During the Construction of the Panama Canal' RCC Perspectives 3 (2015) 19-24 (p. 21).

${ }^{62}$ Andrew Balfour, 'The Term "Tropical”' Journal of State Medicine 33.8 (1925) 360-67 (p. 364).

${ }^{63}$ Andrew Balfour, 'Malaria as an Enemy of the British Empire', p. 5. [MS of address delivered 18 October 1925] London, LSHTM. GB 0809 Balfour/01/07. 
Malaria 'drain[s] our colonies of young lives' just as it 'drain[s] the Empire's resources'; it is a disease

constantly warring against the Empire, now and then sweeping forward and slaying thousands at a time, sapping here, sapping there, picking off $[\ldots]$ our officers, attacking our mercantile marines, crippling our trade and sparing not the women and the children. (14)

Balfour ended his speech by characterising the British empire as one on which 'the sun never sets without infected Anopheline mosquitoes commencing their nefarious work and transmitting the stealthy plasmodium of malaria from the sick to the sound' (15). The vision of malaria as an invisible force sapping energy and draining resources tapped into a dual anxiety about the commercial and practical viability of British imperialism. It was an image also mobilised by British parasitologist John William Scott Macfie (1879-1948) in a poem called 'The Vampire's Grave'.

Macfie spent his early career as colonial medical officer stationed in West Africa and went on to become director of a medical research institute at Lagos and then Accra. He embarked on eight tours of West Africa between 1910 and 1922 and volunteered with the Royal Army Medical Corps (1917-1919) where he investigated malaria with the Liverpool School of Tropical Medicine under the supervision of Ross. He probably wrote 'The Vampire's Grave' whilst stationed in Nigeria in 1911. The poem begins: 'Awake! Awake! Night plays the host, and bide you to your bloody feast/Drink and live till dawn dyes the east. Nigeria! Accursed Coast!' Positioning Nigeria as both personified parasite and host country to parasitic disease, Macfie uses the motif of the vampire to lament the impact of chronic tropical illness on the health of Britons in imperial space. 'How have you fed your phantom life, how many heroes battened on?' he asks.

You laugh to see the new men come, rich red blood pulsing through their veins,

You know with what enduring chains to bind them to their lingering doom, For fatal fascination draws your victims to you year by year,

Do you instil the poison where you suck the lifeblood to your jaws? ${ }^{64}$

${ }^{64}$ London, LSHTM. GB 0809 Macfie/03/02/03. John William Scott Macfie, 'The Vampire's Grave' c. 1911. 
By pairing the sucking of lifeblood with the instilling of poison, Macfie, like Stoker, imaginatively construes the mosquito and vampire as one. The heroes' 'lingering doom' is chronic malaria.

In the late nineteenth century, conceptions of health-especially the health of modern workers - were dominated by a model of 'supply and demand' borrowed from energy physics. It was a model that drew conceptual parallels between the circulation of blood, energy, and money. The finite supply of bodily energy, depleted by physical and mental toil, limited the commercial value of the worker, and so the health and wealth of the nation. As I noted in the previous chapter, energy was often held to be synonymous with 'nerve force', a vocabulary that helped to communicate the wide-reaching impact of the stresses and strains of modern industrial life conceptualised as forms of nervous illness. Macfie's vampire analogy connects this discourse of the depletion of vital and commercial energy to tropical illness, voicing contemporary preoccupations about the repercussions of tropical travel on returning British bodies.

Beyond epidemiological anxieties about acclimatisation, 'The Vampire's Grave' suggests that the British-African imperial relationship is itself parasitic. Nigeria is like a monstrous vampire sucking away the health and wealth of the British nation. Willis flips this ideological position on its head by analysing Dracula as a novel in which the 'middle-class imperialist [is] central to the spread of infection' ${ }^{65} \mathrm{He}$ reads the pivotal scene in which Harker slashes at Dracula with his Kukri knife loosing 'a bundle of bank-notes and a stream of gold', as symbolic of 'the true nature of his relationship with the Count'. Whilst others have read this depiction as a critique of domestic capitalism or unabashed anti-Semitism, Willis interprets the scene as 'a violent colonial confrontation where the British male, with "a fierce and sudden cut" expropriates Transylvania's wealth without recourse to the "civilized" veneer of economic exchange" (321).

Many scholars have since recognised the numerous ways that British imperial relations undergird the narrative. Jill Galvan, for example, has placed Dracula in the context of the cultural legacy of the Indian Rebellion, which, she argues, exerted visible influence on literary culture in the 1890s via Mutiny fiction and the emergence of 'Mutiny Gothic'. Dracula's 'paranoid vision of inverted imperialism', she contends, recalls the event that 'more so than any other in the nineteenth century, brought home to the

${ }^{65}$ Martin Willis, “"The Invisible Giant”, Dracula, and Disease', p. 321. 
British public the vulnerability of empire'. ${ }^{66}$ Drawing parallels between the role of the Indian fakir in spreading dissent among the populace and Dracula's vampirism, Galvan highlights a cultural-literary tradition of quasi-fictional Rebellion lore that would have mediated the public reception of Stoker's novel. She further situates Dracula in relation to Indian Occult culture through his hypnotic abilities, which late Victorians associated with India, and which also became associated - through the figure of the fakir-with the practice of suspended animation through self-hypnosis. Such abilities were mapped onto the cultural profile of the vampire in contemporaneous theosophical works, such as Henry Steel Olcott's 1891 essay 'The Vampire', which connects folkloric notions of vampirism with the Indian fakir's ability to be resuscitated after several weeks' inhumation (441).

Anglo-Indian cultural politics might also be identified in depictions of the proliferating rats that accompany Dracula on his sea voyage and announce his presence at Carfax. Read in the context of the third plague pandemic (1894-1959) — which reached Bombay in 1896-Dracula's rats encode anxiety about contact with indigenous Indian and South Asian reservoirs of disease. The Bombay plague outbreak occupied visible space in the British medical and popular press, which debated the disease's connections to rats as well as the sanitary importance of segregating Europeans from the native population. As the British Medical Journal reported in 1896, several bacteriological investigators were hard at work to elucidate the cause and mode of transmission and particularly 'whether the rat is the primary infector or no'. ${ }^{67}$ As another article noted, Bombay's 'central' position within the empire meant that 'whether seaward or landward the possibilities of spread are enormous'. The author went on to attribute the outbreak to Bombay's 'almost daily communication with the Far East' via steamships:

ships are the chosen home of rats, and their history of being attacked by or enjoying immunity from plague in Bombay may help to clear up the reported part rats play in the life-history of the plague..$^{68}$

${ }^{66}$ Jill Galvan, 'Occult Networks and the Legacy of the Indian Rebellion in Bram Stoker's Dracula', History of Religions 54.4 (May 2015) 434-58 (p. 436).

${ }^{67}$ 'The Plague in India' British Medical Journal 2.1849 (24 October 1896) p. 1254.

68 'The Reported Appearance of Plague in Bombay' British Medical Journal 2.1866 (3 October 1896) p. 996. 
Two of Stoker's brothers were doctors stationed in India during the outbreak, which may well have influenced Stoker's artistic choices. The novel was published at a time when the ontological status of creatures like rats was in flux, still associated with ideas about vermin, but also enjoying new currency as vectors of disease. Thus, Stoker's rats-which Servitje and others have read as part of an anti-Semitic portrayal of Dracula that critiques Eastern European Jewish immigration-embody the combined threat of social and biological mobility. Indeed, the aesthetic of swarming rats was also used to characterise malarial infection; in his treatise on malarial fever, Ross explained that a 'quarter of a billion' malaria parasites must be present to produce fever and that each one inhabits one of the red corpuscles of the blood. They can persist in a patient's blood for years, he asserted, 'just as rats live in a ship'. ${ }^{69}$

For Ross G. Forman, the novel's 'investment in the idea of the bounded nation as a defense against immigration' and its 'reliance on a model requiring an Anglo-American/Northern European alliance to control colonization and to govern geopolitics' dramatises a tension between Greater Britain and Little Englandism (926). The literary cultures of this period produced a range of stories in which writers mobilised the motif of parasitism to link concerns about fracturing gender politics and class conflict with anxieties of reverse-colonisation, from Arthur Conan Doyle's The Parasite (1890) to Florence Marryat's The Blood of the Vampire (1897) to Richard Marsh's The Beetle (1897). In the latter novel, an androgynous foreigner with Occult powers-who literally collapses into an insect vector-is able to gain a foothold in London owing to the precarity of a homeless tramp and the indiscretions of a middle-class politician. ${ }^{70}$

\footnotetext{
${ }^{69}$ Ronald Ross, Malarial Fever; Its Cause, Prevention, and Treatment; Containing Full Details for the Use of Travellers, Sportsmen, Soldiers, and Residents in Malarious Places 9th edn (London and Bombay: Longmans, Green, and Co., 1902) p. 7.

${ }^{70}$ For an extended analysis of the class politics at work in these novels, see: Emilie TaylorBrown, "She has a parasite soul!": The Pathologization of Gothic Monster as Parasitic Hybrid in Bram Stoker's Dracula, Richard Marsh's The Beetle, and Arthur Conan Doyle's "The Parasite"' in Monsters and Monstrosity from the Fin de Siècle to the Millennium ed. by Sharla Hutchinson and Rebecca A. Brown (Jefferson: McFarland and Company, 2015) pp. 12-28.
} 


\section{Biting with Intent: Agency and Revenge}

In 1905, Scottish physician and authority on blood diseases, Dr George Lovell Gulland wrote a letter to Ross enclosing verses he had written to the tune of a popular song called 'Darling Nelly Gray'. ${ }^{71}$ The original song, written by Benjamin Hanby, is the lament of an African-American man whose sweetheart, Nelly, has been sold as a slave and taken away to Georgia. Gulland's version is renamed 'The Lament of the Mosquito' and tells a very different tale. Sung from the perspective of malaria's arthropod vector, it recounts how the disease used to be spread in secret:

We laid our eggs so gaily in the pools beside the stream, And we watched the larvae hatching out with glee, We handed out Malaria to everyone that came, And not a soul suspected it was we!

Later verses, however, explain that the landscape has changed since Ross's discovery. Now 'they've drained our pools away' and covered the larvae in oil. The houses are 'draped in gauze' and the men wear gloves and veils so there are no 'openings' for 'hungry insects'- 'I've forgotten what the taste of blood may be' the mosquito opines. Finally, we learn of a revenge plot:

But to make him feel my vengeance I've devised a little plan,

Which will make him often sadly think of me,

For I'm taking a ship to England, to bite him ere I die,

With a special new disease I've got in store.

The song, written on the way to a country consultation, playfully voices the fear-to use Stephen Arata's phrase-of reverse-colonisation. The mosquito's plan to 'tak[e] a ship to England' directs our attention to the visibility of illness at port hospitals in the bodies of returning soldiers and sailors, appealing to the fear that Britain's geopolitical relationships were immersing the nation in a global market place of pathogens. Moreover, the poem depicts the mosquito 'biting with intent', transforming the vector from a passive vessel into a willing agent in the transmission of disease.

${ }^{71}$ Although he calls it by its first line: 'There's a low, green valley, on the old Kentucky shore'. London, LSHTM. RC. GB 0809 Ross/145/04/01-13. George Lovell Gulland, 'The Lament of the Mosquito', 15 February 1905. 
As Maurits Bastiaan Meerwijk argues, from the 1880s, vectorism became 'a focal point around which popular and long-standing representations of [the mosquito] as a malevolent tropical "predator" were rearticulated'. ${ }^{72}$ Writers reconceptualised mosquitoes as inimical foe rather than environmental annoyances using 'predatory' and 'military' metaphors that attempted to reconcile inherent tensions between the symbolic power of the individual insect, and the collective action that in reality underpinned the transmission of disease. As Ross argued in The Prevention of Malaria (1910): 'it is scarcely true to say that malaria is caused by a parasite and propagated by a mosquito; it can be caused only by many parasites and widely propagated only by many mosquitoes' ${ }^{73}$ We can see these tensions at work in reports of Ross's sanitation work in Freetown, Sierra Leone. In 1901, country gentlemen's newspaper Field published an article on Ross's 'mosquito crusade' in which they recalled that upon finding anopheline mosquitoes Ross had sent a telegram to the Colonial Office, which read simply: 'send men'. They 'smile[d] at the phraseology' because it 'seemed to suggest a larger mosquito than had ever been heard of!'74 Ross was requesting helpers to carry out the work of sanitation-draining swamps, and dousing stagnant water and mosquito larvae with petroleum-nevertheless his choice of words suggested, as the rest of the article makes clear, that he was requesting reinforcements for a military engagement with a single monstrous enemy. ${ }^{75}$

Dracula embodies a similar conceptual tension as both an environmental problem to be sanitised (recall his boxes of soil and alternate forms as mist and dust), and as a specific larger-than-life antagonist. Identifying Dracula as 'an archaic military antagonist [...] who infiltrates England as a pathogenic threat', Lorenzo Servitje uses the Ordnance Survey map as a form with which to explore how the novel holds in suspension tensions between imperial threat and domestic sanitation. As a 'topographical form

\footnotetext{
${ }^{72}$ Maurits Bastiaan Meerwijk, 'Tiger Mosquitoes from Ross to Gates' in Framing Animals as Epidemic Villains. Histories of Non-human Disease Vectors ed. by Christos Lynteris (London: Palgrave Macmillan, 2019) pp. 119-46 (p. 123).

${ }^{73}$ Ronald Ross, The Prevention of Malaria (London: 1910) p. xi.

74 'The Mosquito Crusade’ Field, Saturday 21 September 1901, p. 25.

${ }^{75}$ The military overtones of sanitation work are imported wholesale into Dracula where the Crew of Light carry out their work with a medicalised violence that is supported by the crusading leitmotifs popularised in relation to tropical medicine. Servitje compares the lancet to the sword and the breaking of Lucy's skin for the transfusion of blood to her later impalement by the 'the magnified lance-the stake' (See: Medicine Is War, p. 121).
} 
for military intelligence', the Ordnance Survey, Servitje argues, had been historically active in the 'physical and imaginative construction of empire', from its origins in helping to quell the Jacobite rebellion in the eighteenth century to its utilisation in the mid-nineteenth century by sanitary reformers to map London's drainage and sewerage infrastructure. ${ }^{76}$ At the beginning of the novel, Jonathan Harker visits the British Museum with the intention of finding out more about Transylvania. Alas, he laments 'there are no maps of this country as yet to compare with our own Ordnance Survey maps' (10), a comment that implies superior national selfknowledge and at the same time gestures to an anxious lack of imperial intelligence.

The Count, conversely, has access to a plethora of maps and atlases which he mobilises to garner more intimate knowledge of England and so affect his social and biological invasions. Dracula's use of maps resonates with the role of governmental knowledge in managing and making legible the public health of Britain and her colonies in this period. As Pamela K. Gilbert argues, 'London became the clearest spatial representation of Englishness, and medical mapping of London became a proportionately important mode for representing the health of the social body more generally'. ${ }^{77}$ Cartography was not just a means of visualising space, but rather of presenting 'a statistical argument [...] visually', and understanding social problems spatially (14). Maps created by sanitary reformers like Edwin Chadwick, John Snow, and Charles Booth helped to connect the dots between socioeconomic conditions, unhygienic infrastructures, and epidemic disease.

In 1890, founder of the Salvation Army, William Booth, published In Darkest England and the Way Out, a text inspired by Henry Morton Stanley's In Darkest Africa, published the same year. Whilst Stanley had brought the Congo to life for his readership by imaginatively remapping Britain with an impenetrable and decaying 'Scottish copse' extending 'the entire distance from Plymouth to Peterhead', Booth sought to draw parallels between the jungle and the slum. 'As there is a darkest Africa is there not also a darkest England?' he asks.

Darkest England, like Darkest Africa, reeks with malaria. The foul and fetid breath of our slums is almost as poisonous as that of the African swamp.

\footnotetext{
${ }^{76}$ Lorenzo Servitje, Medicine Is War, pp. 115-16.

${ }^{77}$ Pamela K. Gilbert, Mapping the Victorian Social Body (Albany: SUNY Press, 2004) p. 13.
} 
Fever is almost as chronic there as on the Equator. Every year thousands of children are killed off by what is called defects of our sanitary system. ${ }^{78}$

Booth thus disrupts biomedical boundaries by suggesting that miasmatic colonial geographies figured as natural to the tropics could be reproduced artificially at home by urban poverty. The adverb 'almost'-intended to maintain some semblance of geopolitical difference-crumbles under the weight of the accusation as Booth brings the 'civilising mission' home to bear on what he calls the 'outcast' and 'sinking' underclasses of the Imperial capital. As Alan Bewell, Mark Harrison, and Pamela Gilbert have explored at length, similarities were being drawn in this period between 'othered' colonial landscapes and metropolitan spaces, undermining ideologues like 'primitive' and 'civilised'. The 'tropical' in tropical medicinewhich Manson maintained was 'more convenient than accurate'-was similarly being destabilised by the concept of vectorism. ${ }^{79}$ Regardless of climate or perceived civilisation, if an environment could support the vector, it could support the disease. In 1920, the Western Daily Press would pronounce the possibility of a 'serious outbreak of virulent malaria' in London owing to infected cases coming from abroad and being propagated by local mosquitoes. Referring again to the mosquito as a 'vampire insect', they pointed out that the creatures 'are bred in Hackney and adjoining marshes [and] in the ponds of Wimbledon and Clapham Commons'. 80

As a model for vector-borne illnesses, Dracula draws attention then to the contingent mobility of tropical disease-able to move beyond the boundaries of empire in the bodies of immigrants and returnees, but only able to persist and multiply if supported by particular ecological conditions. As Martin Willis argues, Stoker situates Britain's own infective potential at the 'ancestral' Carfax Abbey and, in doing so, demonstrates that 'predisposing causes of disease are to be found at home as well as abroad'. ${ }^{81}$ This identifies the miasmatic environment as a precondition that already exists within England for the propagation of a 'special new disease', like the one imagined by Gulland's poem. Both 'The Lament of

\footnotetext{
${ }^{78}$ William Booth, In Darkest England and the Way Out (London: Funk \& Wagnalls, 1890).

${ }^{79}$ Patrick Manson, Tropical Diseases: A Manual of the Diseases of Warm Climates (London: Cassell and Company 1898), p. xi.

80 'Mosquito Menace' Western Daily Press, Thursday 19 August 1920, p. 8.

${ }^{81}$ Willis, “"The Invisible Giant”, Dracula, and Disease', p. 320.
} 
the Mosquito' and Dracula sit within a 'history of disease representations that persistently racialize populations and environments associated with disease via the gothic figures of the alien, the rogue, the vampire, the zombie, the monster, [and] the terrorist' ${ }^{82}$ Whilst Stoker overtly medicalises racial alterity in his characterisation and plot, the form of Gulland's poem implicitly does the same. Gulland likely chose 'Darling Nelly Grey' as a base simply for its popularity; nevertheless, the original lyrics provide an uncomfortable undertone, drawing perhaps unintended connections between imperial sanitary administration and the slave trade. By positioning African-Americans and mosquitoes in the same lyrical space, Gulland implicitly performs a common rhetorical technique that collapsed parasites, vectors, and indigenous populations into one.

As Emily Alder has argued, from the late century onwards changing depictions of human-animal encounters helped to shape the development of science fiction, especially in relation to non-human subjectivities. This is particularly clear in the Weird Fiction subgenre closely identified with the American fantasy and horror fiction magazine Weird Tales, and the work of H. P. Lovecraft. These tales, Alder argues, 'unsettle a colonialist centrism structuring relationships between humans and the more-thanhuman world' ${ }^{83}$ This unsettling of colonialist centrism is evident in a short story called 'Wingéd Death', which uses sleeping sickness and its tsetse fly vector to disrupt ideas about human and non-human agency, and to undermine imperialist hierarchies of knowledge. Published in Weird Tales in 1934, 'Wingéd Death' was ostensibly ghost written by H. P. Lovecraft in collaboration with American pulp fiction writer Hazel Heald, who supplied the original idea and plot.

The narrative opens with four men: the hotel proprietor, a policeman, a coroner and his physician, standing in a hotel room in Bloemfontein, South Africa (incidentally where Arthur Conan Doyle was a doctor during the Anglo-Boer war). Their 'horror' is 'equally divided' between the dead body in front of them, a journal in the physician's hand, a dead fly in a pot of ammonia, and some handwriting scrawled on the ceiling. The remaining narrative is taken directly from the journal, which belonged to the dead man, who is both the victim and perpetrator of a murder. Like 'The

\footnotetext{
${ }^{82}$ Neel Ahuja, Bioinsecurities: Disease Interventions, Empire, and the Government of Species (Durham: Duke University Press, 2016) p. 15.

${ }^{83}$ Emily Alder, '(Re)Encountering Monsters: Animals in Early Twentieth Century Weird Fiction' Textual Practice 31.6 (2017) 1083-100.
} 
Vampire's Grave', 'Wingéd Death' cultivates a relationship between Africa, disease, and revenge, and like With Edged Tools, it plays on a popular association between sleeping sickness and superstition. The story follows Dr Thomas Slauenwite, an American pathologist specialising in African fevers, who enacts a complicated scheme of revenge on a scientific rival, Professor of Invertebrate Biology at Columbia University, Dr Henry Moore, $\mathrm{PhD}$. Slauenwite had developed a theory about the transmission and development of remittent fever, aided 'only slightly' by some papers belonging to a late government official named Sir Norman Sloane. Following his work, Slauenwite was in line for a cushy position in the South African health service and even a knighthood. However, Moore had undermined his claim to precedence by publishing correspondence he had with Sloane before his death that revealed that Sloane had come to the same conclusion, and before Slauenwite. Slauenwite is 'ruined' by the accusation of plagiarism and although the British government ignored the aspersions, they 'withheld the half-promised appointment and knighthood'. He subsequently moves to a cotton and ivory trading-post at M'Gongo,

a beastly hole $[\ldots]$ full of every sort of fever known to mankind. Poisonous snakes and insects everywhere, and niggers with diseases nobody ever heard of outside medical college. ${ }^{84}$

There he comes across a man called Mevana who is suffering from 'a queer illness' after being bitten by an insect. The locals believe that he has been bitten by a 'devil-fly' which

makes its victim waste away gradually and die, and then takes hold of his soul and personality if it is still alive itself-flying around with all his likes, dislikes, and consciousness. (36)

Slauenwite gives him quinine and takes a sample of his blood. He is initially mystified by the 'strange germ' he sees beneath the microscope, but after reading an old volume of local health records, he realises that it is sleeping sickness from which Mevana is suffering and that he must have been bitten by a tsetse fly. Slauenwite is suddenly stuck with the means by

${ }^{84}$ H. P. Lovecraft and Hazel Heald, 'Wingéd Death' in Black Seas of Infinity: The Best of H. P. Lovecraft, selected by Andrew Wheeler (Garden City, NY: SFBC Science Fiction, 2001) pp. 33-54 (pp. 35-36). 
which he might exact revenge upon Moore (who is an authority on African entomology): send him a never-before-seen species of fly infected with the trypanosome parasite. He sets about creating his 'envoy of death' by crossbreeding different species of tsetse fly and spraying their wings blue in the hope of luring Moore to try to classify it. After several experiments on his indigenous servants, Slauenwite is satisfied that the cross-bred flies are infective (his house-boy, Batta, dies after being bitten) and so he mails a batch to Moore.

However, after reading of Moore's death several months later in the Mombasa Gazette, the idea that the fly 'steals' its victim's consciousness, which he initially dismissed as native superstition, briefly takes hold of Slauenwite:

One thing at the very end of the report-undoubtedly, the cheap romancing of a yellow journalist - gives me a curious shudder in view of the legends of the blacks and the way the fly happened to go wild when Batta died. It seems that an odd incident occurred on the night of Moore's death; Dyson having been aroused by the buzzing of a blue-winged fly-which immediately flew out the window-just before the nurse telephoned the death news from Moore's home, miles away in Brooklyn. (44)

After Batta died the fly that bit him appeared to commit suicide and after Moore died the fly 'escaped' out of the window with perceived intent. With mounting suspicion cast in his direction, Slauenwite flees to Johannesburg under an assumed identity.

A few months after Moore's death, and three years after the first journal entry, Slauenwite takes to writing in it again, this time 'solely to relieve [his] mind'. He is being tormented by a blue-winged tsetse fly, which he begins to believe might contain his dead rival's consciousness. The diary entries become increasing frantic as Slauenwite begins to question his own sanity:

Jan. 16-Am I going insane? [...] I must keep a tight hold of my consciousness.

Jan. 17-Either I am mad or the world is in the grip of some sudden suspension of the laws of probability, as we know them [...]

Jan. 18-Into what strange hell of living nightmare am I plunged? [...]

Jan. 19-I am utterly engulfed in horror. (46-49) 
The fly hovers around a copy of Henry Moore's book Diptera of Central and Southern Africa, knocks on windows and doors, and begins a haunting count down by dipping itself in ink and scrawling numbers on the ceiling: 'Five, four, three, two - what can this be save some monstrous and unthinkable counting-off of days?' When the countdown reaches two, Slauenwite flees to Bloemfontein, but, to his horror, the fly follows him. As the diary entries recede and we are returned to the frame narrative, the reader is faced with an interpretive dilemma. Slauenwite's distrust of his own senses, the references to his 'shaken' mind, and even his handwriting-which, we are informed, becomes 'irregular, nervous and very difficult to decipher'-undermine the veracity of his perspective. Thus, the ending, with its dead body and accompanying paraphernalia, can be interpreted in two ways: that the narrator has contracted sleeping sickness and the diary recounts his gradual mental deterioration as a result of the illness, or that he really was being hounded by a supernatural arthropod. The cause of death is noted by the coroner as 'heart-failure induced by sheer fright', but he admits the presence of a tsetse fly bite on the back of Slauenwite's neck, along with trypanosomes in his blood, keeping both possibilities in play. The writing on the ceiling, supposedly written by Slauenwite in fly-form, appears to corroborate his story. It reads:

\section{SEE MY JOURNAL-IT GOT ME FIRST-I DIED-THEN I SAW I WAS IN IT-THE BLACKS ARE RIGHT-STRANGE POWERS IN NATURE-NOW I WILL DROWN WHAT IS LEFT. (54)}

The drowned fly in a pot of ammonia is alleged to be Slauenwite's suicide after he realised that his consciousness had been transferred into the fly's body. The coroner asserts that the position of the writing is in a place 'no human hand could reach', which again appears to confirm the authenticity of the supernatural. In a narrative that refuses to fully confirm or negate the teller's perspective, the 'mysteries of Africa', articulated by native superstition, are pitted against, and ultimately supersede, the scientific authority of Western biomedicine. As Slauenwite writes: 'Too often a grain of incredible truth lurks behind the wildest and most fantastic of legends' (52).

In a letter to fellow weird fiction author Clarke Ashton Smith in 1934, Lovecraft explained the genealogy of 'Wingéd Death' as follows: 
All Mrs. Heald had to start with was a cloudy idea about somebody killing somebody with bugs. Then she got a medical friend to shed some light on poisonous African insects, \& decided to give the tale an African cast. That was all I had to go on. ${ }^{85}$

Like Arthur Conan Doyle's earlier story 'The Adventure of the Dying Detective', 'Wingéd Death' makes use of the obscurity and lethality of tropical disease as a bioweapon for enacting revenge. Unlike 'Dying Detective' however, 'Wingéd Death' does not find a comforting resolution in the authority of Western medical knowledge. In revising Heald's idea-itself already full of ghoulish potential-Lovecraft could not resist dropping in cross-references to his Cthulhu mythos, a shared fictional universe created by Lovecraft in the early twentieth century and expanded by his contemporaries. When Slauenwite ventures into the jungle to look for sleeping sickness-infested tsetse flies he comes across some Cyclopean ruins, which the locals give a wide berth:

They say these megaliths are older than man, and that they used to be a haunt or outpost of 'The Fishers from Outside' - whatever that means - and of the evil gods Tsadogwa and Clulu. To this day they are said to have a malign influence, and to be connected somehow with the devil-flies. (38)

The Fishers from Outside appear in a poem by Lovecraft written five years earlier called 'The Outpost' (1929) in which ancient ruins in Zimbabwe are attributed, not to past human civilisation, but to alien colonisation. By making Tsadogwa and Clulu-degenerations of the names 'Tsathoggua' and 'Cthulhu' (cosmic alien deities from the Cthulhu mythos)-responsible for malign influence (sleeping sickness) and devil-flies (tsetses), Lovecraft rescripts tropical epidemiology as otherworldly. Thus, whilst Will Tattersdill has argued that science fiction often brought colonialism to outer space, Lovecraft's weird fiction quietly does the opposite. ${ }^{86}$ Like so many imperial cartographers, Lovecraft erases African history, replacing it with an alien alterity that enacts the ultimate colonial Othering. As

${ }^{85}$ [H. P. Lovecraft to Clark Ashton Smith, dated 9 March 1934] in Dawnwood Spire, Lonely Hill: The Letters of H. P. Lovecraft and Clark Ashton Smith: 1932-1937, ed. by David E. Schultz and S. T. Joshi (New York: Hippocampus Press, 2020) p. 544.

${ }^{86}$ See: Will Tattersdill, Science Fiction and the Fin-de-Siècle Periodical Press (Cambridge: Cambridge University Press, 2016). 
David Simmons has argued, Lovecraft and Stoker ultimately 'use the nonWestern as a signifier of horror' ${ }^{87}$

From cautionary tales of Martian invasion to imperialising vampires, fin de siècle engagements with parasite-vector-host relationships provide forms that both question and reinforce a 'geography of blame for epidemic diseases transmitted by non-human animals' ${ }^{88}$ This deeply problematic conceptual language continues to inform popular narratives about global disease transmission and immigration, which equate epidemics with threats to national security. Mosquitoes were depicted in public health communications well into the twentieth century as 'wild beasts and monsters, vamps, vampires [...] killer[s], criminal[s], [and] terrorist[s]'. ${ }^{89}$ Such predatory metaphors collapse parasite and vector into one monstrous figure that, in turn, does political work as a shorthand for racial and cultural difference. From depictions of plague-carrying rats with Chinese faces, to characterisations of mosquitoes as international terrorists, to caricatures of Soviet politicians as rabid dogs, 'the image of animals as enemies of humanity assumed anthropomorphic aspects, which under a colonist gaze involved racist inflections'. ${ }^{90}$ At the same time, analogies of military violence and of medical crusading have guided western biomedicine towards a colonialist approach to the body that is increasingly at odds with the emerging importance of microbial 'multiculturalism'. ${ }^{91}$ By excavating the rhetorical and formal entanglements between the ecologies of illness and our relationships with global, racial, and social others, we gain critical insight into how medical narratives have been weaponised to delimit the human and to inscribe difference.

${ }^{87}$ David Simmons, “"A Certain Resemblance”: Abject Hybridity in H. P. Lovecraft's Short Fiction' in New Critical Essays on H. P. Lovecraft ed. by David Simmons (New York: Palgrave Macmillan, 2013) pp. 13-30 (p. 14).

${ }^{88}$ Frédéric Keck, 'Postscript: Epidemic Villains and the Ecologies of Nuisance' in Framing Animals as Epidemic Villains: Histories of Non-human Disease Vectors ed. by Christos Lynteris (London: Palgrave Macmillan, 2019) p. 229.

${ }^{89}$ Maurits Bastiaan Meerwijk, 'Tiger Mosquitoes from Ross to Gates', pp. 139-40.

${ }^{90}$ Christos Lynteris, 'Introduction: Infectious Animals and Epidemic Blame', pp. 16-17.

${ }^{91}$ Microbiome studies in particular has ushered in a suite of ecologically inflected metaphors for understanding intra-organismal relationships that provide an alternative to the lexis of militant self/other immunology. 
Open Access This chapter is licensed under the terms of the Creative Commons Attribution 4.0 International License (http://creativecommons.org/licenses/ by $/ 4.0 /$ ), which permits use, sharing, adaptation, distribution and reproduction in any medium or format, as long as you give appropriate credit to the original author(s) and the source, provide a link to the Creative Commons licence and indicate if changes were made.

The images or other third party material in this chapter are included in the chapter's Creative Commons licence, unless indicated otherwise in a credit line to the material. If material is not included in the chapter's Creative Commons licence and your intended use is not permitted by statutory regulation or exceeds the permitted use, you will need to obtain permission directly from the copyright holder. 